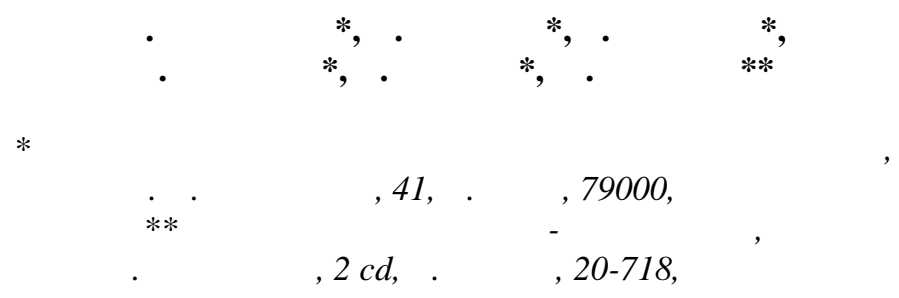

околицях с. овге в но- $\mathrm{p}$ нківської обл. прекр сно розвинені четверт , п’ят , шост н д3 пл вні тер си ністр . жливо, що вони розміщені поряд і доступні для вивчення н всю висоту. озрізи п’ятої і шостої тер с опубліков ні н ми р ніше. ижче н ведено дет льний опис четвертої тер си.

сі високі тер си околиць овгого цокольні. іхній будові, окрім цоколя, добре вирізняються русловий гр війно-г лечниковий лювій, з пл вний піщ но-супіщ но-суглинистий лювій і покривні суб ер льні лесово-грунтові п чки різної потужності. розрізі четвертої тер си предст влені дуже повні профілі грунтів першої і другої ф з коршівського грунтоутворення 3 г льною потужністю 3,6 м. ому коршівський викопний грунтовий комплекс у розрізі овге може бути опорним для ередк рп ття.

лючові слов : тер с , лювій, суб ер льні покриви, лесово-грунтові серії, похов ні грунти, грунтові комплекси, п леоліт.

р гмент долини ністр в околицях овгого, що з 10 км униз з течією від гирл истриці, є дуже цік вим і н дзвич йно в жливим. е зумовлено тим, що тут н невеликій ділянці долини річки прекр сно розвинені високі н дз пл вні тер си ністр четверт , п'ят і шост . они не тільки добре вир жені в рельєфі (див. рис. 1), й м ють доступні для вивчення розрізи. розріз х тер с відслонені цоколі (див. рис. 2), люві льні п чки т покривні лесово-грунтові товщі. тже, у р йоні с. овге скл лись сприятливі умови для всебічного геолого-геоморфологічного н лізу тер с, ділянк долини ністр може претендув ти н роль ет лонної.

ізновисотні тер си ністр в околицях овгого описув в · олянський. ін дослідив тут нем ло розрізів, конст тув в різновікові покриви лесів 3 похов ними грунт ми тощо. . олянський ув ж в цей р йон дуже перспективним для вивчення п леоліту, опис вши ртеф кти в триг нцях (крем'яні ртеф кти пізньооріньяцької культури, теріоф уну, попелищ ), ошневі (кістки Elephas primigenius Blum. зі слід ми діяльності п леолітичної людини, Arctomys bobak, т кож крем'яні ориньяцькі вироби). ріямполі . олянський виявив кільк культурних п леолітичних горизонтів [1].

орфологічні т морфометричні риси шостої і п'ятої н дз пл вних тер с, які розвинені в околицях с. овге, т результ ти досліджень плейстоценових відкл дів, що їх скл д ють, опубліков ні н ми р ніше $[2,3,6]$. оверхня шостої н дз пл вної тер си

(C) огуцький ., цишин ., митрук . т ін., 2012 
(рівня оєвої), як формує тут брівку долини ністр, піднім ється н 85-95 м н д руслом річки, іiї цоколь - н 75-80 м. ля п'ятої н дз пл вної тер си морфометричні пок зники т кі: відносн висот поверхні тер си -55-75 м, цоколю-до 25 м.

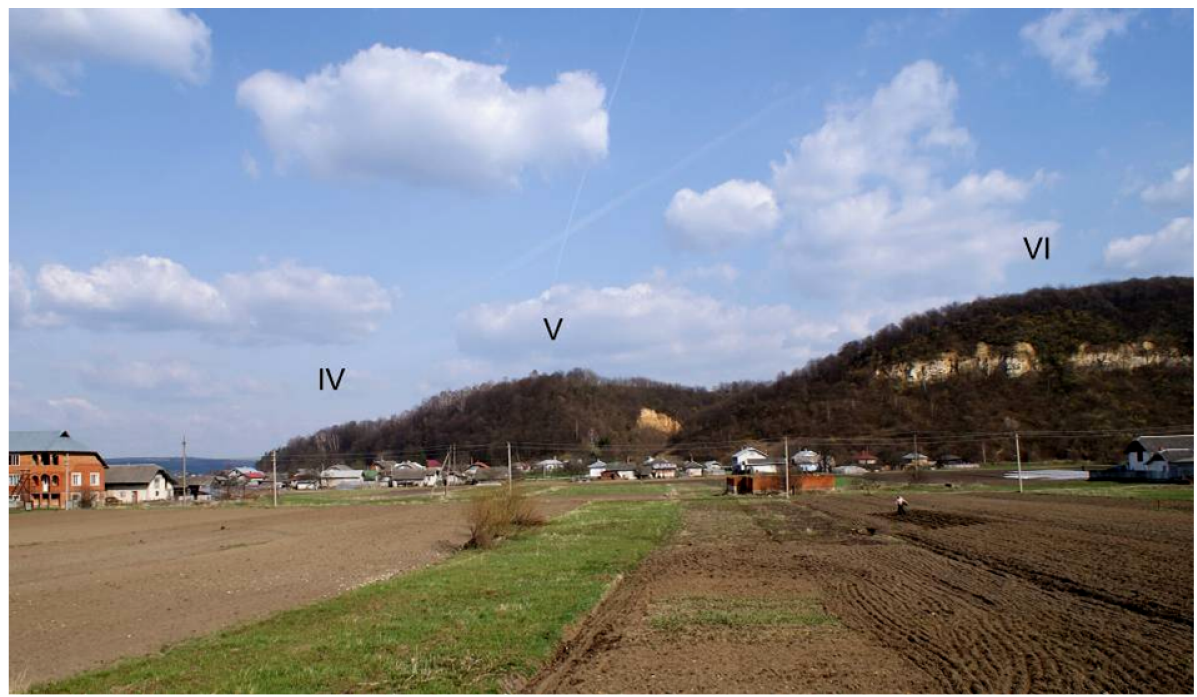

ис. 1. исокі тер си ністр в околицях с. овге.

лі ми дет льніше сх р ктеризуємо четверту н дз пл вну тер су ністр . ер с розвинен н південно-східній і східній околицях овгого і н відст ні м йже 500 м відслонен у пр вому крутому борті долини. оверхня тер си розт шов н в меж х 230-240 м, що ст новить 30-40 м н д руслом ністр .

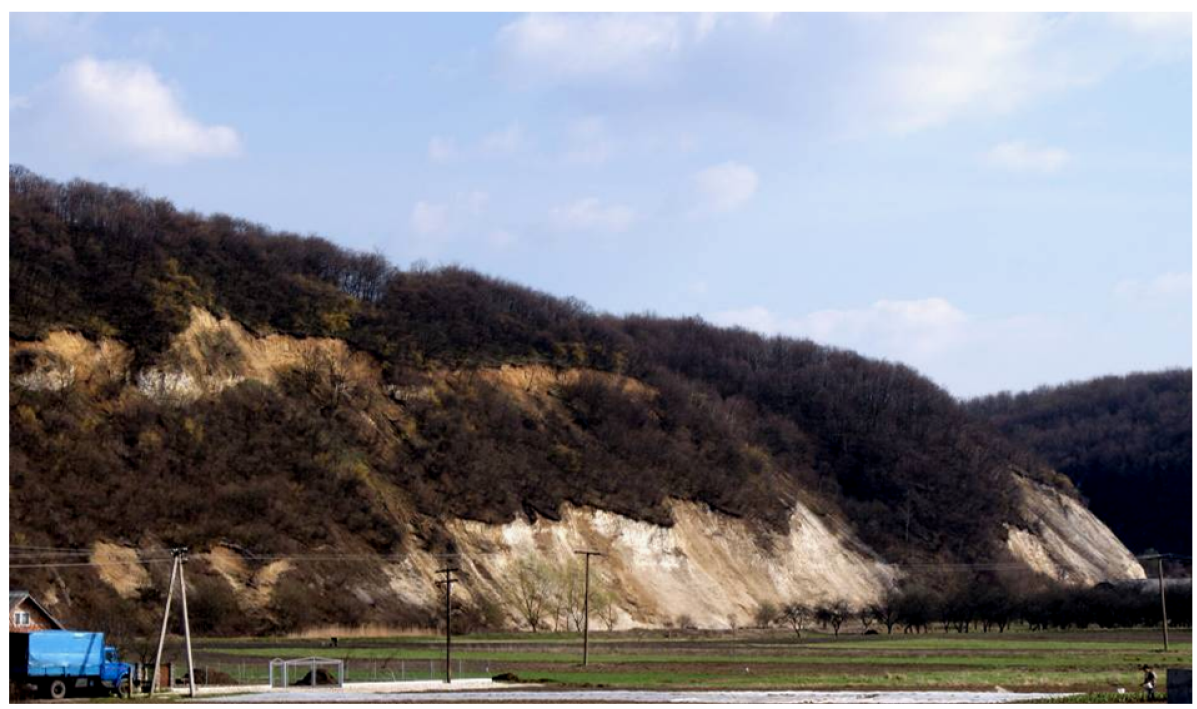

ис. 2. ерхньокрейдовий цоколь шостої тер си ністр в околицях с. овге. 
писув ний розріз - це крутий уступ тер си ністр н східній околиці овгого (урочище овге-гор ). бсолютн відмітк овге-гори - 239,4 м, уріз води у ністрі близько 201 м, тобто висот тер си ст новить дещо менше 40 м.

уч сний грунт, сформов ний н горохівському викопному грунлибин , м $0-2,0$ товому комплексі. $є$ добре диференційов ний профіль:

0-0,4 м - гумусний ( ) горизонт. упіщ ний, темно-сірий, безк pбон тний, переповнений корінням рослин, у нижній ч стині $з$ підзолистою білястою присипкою. нтропогенно порушений пр ктично н всю потужність. ижній конт кт ясний, з зміною кольору.

0,4-0,8 м - елюві льний ( ) горизонт. упіщ ний (пудр ), білястий, 3 к к о-коричневим відтінком, м кропористий, плитч стий. рекр сно виділяється у розрізі.

0,8-2,0 м - ілюві льний ( ) горизонт. углинистий, червонув токоричневий, великопризм тичний, дуже тріщинув тий, оз лізнений, у нижніх 0,3-0,4 м смуг стий. углинки дуже щільні, безк рбон тні. ижній конт кт фіксов ний з появою з кип ння з 1.

еси однорідні, супіщ ні, жовтув то-сірі (п леві), з псевдоміцелі$є м$, поодинокими смуг ми і плям ми оз лізнення, вертик льнотріщинув ті, що особливо добре видно н стінк х, які підсохли. еси н всю потужність вз ємодіють $3 \quad 1$. ижній конт кт ясний, $з$ зрост нням оглеєння і появою смуг бурого оз лізнення.

лейовий горизонт. упіщ ний, жовтув то-сірий, ділянк ми з голубув тим відтінком, ш рув тий. рув тість виділяється кольором, смуг ми бурого оз лізнення, т кож н явністю лінз світло-сірих різнозернистих пісків потужністю до 3-5 см. ісцями смуги оз лізнення спостеріг ють через 0,5-1,0 см, що може свідчити про неповносітч сту п леомерзлотну текстуру п чки. оризонт н всю потужність сл бко 3 кип є 3 1, м йже не містить вторинних к рбон тних новоутворень. ижній конт кт різкий, очевидно, ерозійний. мінюються колір порід і їхній гр нулометричний скл д.

тр тигр фічно цей ш р може відповід ти $л$ новецькому підгоризонту, що у шостій киснево-ізотопній ст дії.

ш ру відібр но і промито чотири проби н м л коф уну:

1 - відібр н біля верхнього конт кту ш ру;

2 - з глибини 7,2 м;

3 - 3 глибини 7,4 м;

4 - біля нижнього конт кту ш ру.

ерш і друг проби виявились пустими (не містили м л коф уни), у пробі 4 тр пились поодинокі екземпляри молюсків, н йб г тшою є проб 3 (228 екземплярів молюсків). н ліз ф уни н ведений нижче.

упіщ, ний горизонт. верхній ч стині червонув то-коричневий, у нижній - світліший, жовтув то-сірий. ороди сл бко з кип ють 3

1, оглеєні, однорідні, з великою кількістю бурих з лізистом нг нових новоутворень (до 2 мм). ижній конт кт ясний, 3 зміною 
кольору і великою кількістю біогліфів (світлих плям, очевидно, орг нічного походження).

л бко розвинений грунт (глейовий горизонт ?) н д тернопільським підгоризонтом. ін м є генетичний профіль:

умусний ( ) горизонт потужністю 0,2 м. кл дений супіск ми легкими, однорідними, оглеєними, світло-коричневими, з червонув тим відтінком. углинки сл бко вз ємодіють 3 1, містять чорні і бурі з лізисто-м нг нові новоутворення (до 2 мм у ді метрі) і плямибіогліфи (до 10 см). ерехід поступовий, з зміною кольору.

оризонт промитий н м л коф уну (проб 5).

люві льний ( ) горизонт потужністю 0,5 м. кл дений супіск ми, жовтув то-сірими, місцями з голубув тим відтінком, оглеєними, що переповнені чорними з лізисто-м нг новими конкреціями (до 3 мм ді метром). ісцями тр пляються чорні м нг нові плями (до 10 см). упіски н всю потужність 3 кип ють $3 \quad 1$. ерехід 3 зміною кольору, поступовий.

оризонт промитий н м л коф уну (проб 6), проте молюсків не виявлено.

г лом близький до опис ного вище похов ний грунт, очевидно, тернопільський підгоризонт. є гумусний ( ) горизонт потужністю 0,2 м. кл дений легкими супіск ми, н гр ні глинистих пісків, жовтув то-коричневий, безк рбон тний, з біогліф ми і чорними з лізисто-м нг новими новоутвореннями (до 3 мм у ді метрі). іля тріщин $\epsilon$ вторинні к рбон ти. ерехід поступовий.

оризонт промитий н м л коф уну (проб 7), одн к молюсків не виявлено.

люві льний ( ) горизонт потужністю 0,3 м. кл дений легкими супіск ми, н гр ні глинистих пісків. ороди горизонту не вз ємодіють 31 , містять зн чну кількість чорних 3 лізисто-м нг нових новоутворень (ді метром до 3 мм).

ля дослідження ф уни молюсків ми відібр ли сім проб з н дкоршівської ч стини розрізу. с кожного зі зр зків ст новил близько 15 кг. ромив ння виконув ли н ситі з ді метром лунки 0,6 мм. ун молюсків виявил сь лише у трьох із відібр них семи зр зків. пробі 4, як відібр н з нижньої ч стини л новецького підгоризонту, ф ун предст влен здебільшого детритом, іiі кількість невелик , окремі екземпляри визн чені лише до родини. н йдену ф уну н ведено у т блиці.

сю ф уну ми розділили н чотири екологічні групи $[4,7]:$ - мезофільні види;

- види відкритих ценозів; F - види з тінених ценозів; W - водні види. крім ф уни молюсків, у зр зку 4 виявлено остр коди.

p ктерно, що у всіх зр зк х зн йдено холодостійкі (холодолюбні) види, які є визн ч льними і свідч ть про формув ння товщі в холодних умов х тундр (тундро-лук, тундро-степів, можливо, лісотундри). о т ких видів з числяємо Pupilla loessica, Pupilla densegerata, Vallonia tenuilabris, Columella columella. явність першого виду 3 свідчує можливість тогоч сних процесів лесон гром дження. омінув ння в скл ді кожної з проб мезофілів, у вип дку зр зК 4 в поєдн нні з водними вид ми т остр код ми, є озн кою досить зн чної зволоженості території. е можн пояснити розт - 
шув нням розрізу безпосередньо поблизу ністр т близькістю до рп т, які $є$ і були регіоном підвищеної кількості оп дів.

\begin{tabular}{|l|c|c|c|c|}
\multicolumn{1}{|c|}{ ун молюсків розрізу овге (четверт тер с ) } \\
\hline \multicolumn{1}{|c|}{} & & \multicolumn{2}{l|}{} \\
\hline земні в иди & & $\mathbf{3}$ & $\mathbf{4}$ & $\mathbf{5}$ \\
\hline Succinea oblonga & & 124 & 3 & 7 \\
\hline Pupilla muscorum & & 28 & 2 & 3 \\
\hline Pupilla loessica & & 36 & - & 4 \\
\hline Pupilla densegerata & & 5 & - & - \\
\hline Pupilla steri & & 1 & - & - \\
\hline Vallonia tenuilabris & & 29 & 1 & - \\
\hline Columella columella & & 4 & - & - \\
\hline Trichia hispida & & - & - & 2 \\
\hline Arianta arbustorum & F & 1 & - & - \\
\hline \multicolumn{1}{|c|}{ одні в иди } & & & & - \\
\hline Lymnaea sp. & W & - & 1 & - \\
\hline Gyraulus albus & W & - & 1 & - \\
\hline Segmentina nitida & W & - & 1 & - \\
\hline Sphaerium sp. & W & - & 1 & $\mathbf{1 6}$ \\
\hline г ль н кількість & & $\mathbf{2 2 8}$ & $\mathbf{1 0}$ & \\
\hline
\end{tabular}

н хідк у зр зку 3 т ксон Arianta arbustorum, який є тіньолюбом, може свідчити про існув ння в долині ністр осередків деревної рослинності, що узгоджується 3 результ т ми попередніх н ших досліджень $[5,6]$. ік в зн хідк в цьому ж зр зку Pupilla sterri - виду, який є типовим для добре освітлених, сухих біотопів. е д є підст ви говорити про існув ння у той ч с н досліджув ній території л ндш фтів типу тундро-степів, які чергув лися 3 п нівними тундро-лук ми. видше 3 все, ч стк перших зрост л з відд ленням від долин рік - тобто у бік вододілів т високих н дз пл вних тер с.

йм'якші умови х р ктерні для ч су формув ння нижньої ч стини л новецького підгоризонту, про що свідч ть зн хідки у відібр ному з нього зр зку 4 мезофілів, водних ст гнофільних форм т остр кодів. иповими були у той ч с соліфлюкційні процеси, з болочення, н вирівняних ділянк х формув ння тимч сових водойм (к люж).

трим ні результ ти доповнюють н ше б чення умов формув ння лесово-грунтової товщі лицького ридністер'я під ч с шостої киснево-ізотопної ст дії.

$$
\text { оршівський викопний грунтовий комплекс. кл дений повно- 9,3-12,9 }
$$
профільними грунт ми двох ф з грунтоутворення.

икопний грунт другої $\phi з и$ коршівського комплексу. $є$ потужний (0,6 м) гумусний ( ) т ілюві льний ( ) потужністю 1 м горизонти. есь сформов ний н легких супіск х, іноді - глинистих піск х.

умусний ( ) горизонт досить однорідний, не вз ємодіє з 1 , жовтув то-коричневий, з червонув тим відтінком і великою кількіс- 
тю біогліфів (до 10 см у ді метрі). ерехід поступовий, ле дуже нерівний, з зміною кольору і зрост нням біогенної переробленості.

р нулометричний скл д порід в ілюві льному ( ) горизонті пр ктично не змінюється, проте різко збільшується біогенн переробленість - це червоточини (до 1,5 cм), кротовини (до $10 \mathrm{~cm}$ ) і біогліфи-вицвіти ниркоподібної форми (до 12 см). червоточини і кротовини, з повнені як досить темним м тері лом гумусного горизонту, т к і лесом. ерехід ясний, з зміною кольору, дуже нерівний.

чевидно, між першою і другою ф з ми коршівського комплексу існув л перерв, про що кр сномовно свідч ть тріщини, які з повнені лес ми і розпочин ються з поверхні першої ф зи. ріщини м ють глибину до 0,6 м і ширину до $10 \mathrm{~cm}$. користь цього припущення можуть свідчити і кротовини (ді метром до 10 см), з повнені лес ми. ротовини простежені в гумусному горизонті грунту першої ф зи коршівського комплексу.

рунт першої $\phi з и$ коршівського грунтоутворення. ого потужність ст новить 2,0-2,2 м із-3 нерівних верхнього і нижнього конт ктів.

умусний ( ) горизонт першої ф зи коршівського комплексу дуже х р ктерний і потужний (до 1 м і більше). ерхніх 0,3 м - супіски коричневі, дуже біогенно перероблені (лесові кротовини, вицвіти і червоточини з досить темним гумусним н повнюв чем). е, очевидно, ді генетично змінен ч стин горизонту .

ентр льн ч стин горизонту потужністю до 0,5 м т кож супіщ н , темно-коричнев , місцями до чорної, дуже біогенно перероблен : велик кількість кротовин (до 10 см ді метром), з повнених лесом, червоточин (до 2 мм), з повнених лесом і гумусним м тері лом. ороди 31 не вз ємодіють, проте місцями тр пляються вторинні к рбон ти. ерехід поступовий.

нижній ч стині горизонту потужністю до 0,3 м колір змінюється н жовтув то-коричневий. ороди супіш ні, не вз ємодіють 3

1, одн к місцями тр пляються вторинні к рбон ти. упіски біогенно перероблені (кротовини і червоточини), з дуже нерівним нижнім конт ктом.

p пляються ділянки, де гумусний горизонт знижується у вигляді мульдоподібних тіл ще н 0,2-0,3 м. ирин цих мульд до 0,5 м. они є через кожні 1,7-2,0 м.

люві льний ( ) горизонт першої ф зи коршівського комплексу з г льною потужністю близько 1 м (11,9-12,9 м) сформов ний н оструктурених легких супіск х, іноді глинистих піск х. ороди червонув то-коричневі. основній м сі не вз ємодіють 3 1, проте містять гнізд вторинних к рбон тів ді метром до $1 \mathrm{~cm}$ і більше. ороди досить щільні, оз лізнені, з великою кількістю, особливо у верхній ч стині, червоточин (до 1,0-1,5 см і більше) і кротовин (до 10 см і більше), з повнених гумусним темно-сірим м тері лом. іля нижнього конт кту горизонту з'являється ш рув тість, зрост є опіщ неність, що не тільки відчув ється в гр нулометричному скл - 
ді, й у піщ них прош рк х, потужністю до 3-5 см. ижній конт кт ясний, з зміною літології.

муг $\mathrm{cm} n$ чк, як предст влен переш рув нням головно глинистих пісків із різною зб г ченістю глинистими ч стинк ми і різного кольору. олір коричневий і світло-сірий. отужність окремих прош рків до 10-15 см. рув тість горизонт льн . кротовини, здебільшого коричневі (з горизонту ) і темно-сірі (з горизонтів т коршівського комплексу). цьому смуг стому горизонті, особливо у його верхній ч стині, відчув ється вплив коршівського грунтоутворення.

упіски (близькі до глинистих пісків) тонкош рув ті, ш рув тість виділен головно кольором, точніше - прош рк ми світлішого фону н 3 г лом жовтув то-сірій основі. іски безк рбон тні. ижній конт кт ясний, з появою к рбон тності.

іски глинисті, однорідні, світло-сірі, переповнені вторинними к рбон т ми. рбон ти у вигляді білих включень (до 1 см у ді метpi), пухкі. ижній конт кт ясний. ороди ст ють безк рбон тними.

іски дрібнозернисті, жовтув то-сірі, однорідні, з ясним нижнім конт ктом.

лейов $n$ чк. іш н , у верхній ч стині голубув то-сір , дуже оглеєн й оз лізнен, переповнен плям ми бурого оз лізнення (до 1 см у ді метрі). ноді ці плями з ляг ють горизонт льно, виділяючи ш рув тість пісків. ижня ч стин п чки менш оглеєн, проте зб гчен гр війно-г лечниковим м тері лом (добре обк т ні г льки пісковиків, до 3-4 см у ді метрі). ижній конт кт ясний, 3 зміною кольору і гр нулометричного скл ду.

іски різнозернисті, жовтув то-сірі, головно горизонт льнош рув ті, н окремих ділянк х $з$ великою кількістю з лізисто-м нг нових чорних новоутворень. ижній конт кт ясний, різкий, з зміною кольору і гр нулометричного скл ду.

іски глинисті, до супісків, горизонт льнош рув ті, голубув то-сірі (прекр сний глейовий горизонт). рув тість виділен смуг ми бурого оз лізнення (до 1 см потужністю). ш рі тр пляються добре обк т ні г льки пісковиків (до 3-4 см). творення цього ш ру пов'яз не, очевидно, з геохімічним 6 р'єром, розвиненим н конт кті з русловим лювієм. условий лювій здебільшого горизонт льнош рув тий. ксим льний розмір г льок пісковиків - до 5-7 см, вони прекр сно обк т ні. ерхній 1 м товщі дуже оз лізнений, з огляду н що м є бурий колір, i ом нг нов ний, через що м є чорний колір. е, очевидно, н слідки геохімічного 6 р'єр .

іски - головний н повнюв ч гр війно-г лечникового м тері лу, іноді вони ст новлять 30-40 \% руслового лювію.

основі руслового лювію розміри г льок збільшуються до $15 \mathrm{~cm}$, вони т кож прекр сно обк т ні.

гр війно-г лечниковій товщі, крім пісковиків, тр пляються червонув то-бурі силіцити, молочно-білий кв рц тощо. 
лечник з ляг є н крейдовому цоколі, побудов ному кременистими мергелями. исот цоколю - 8,3 м (колив ється в меж х 8-10 м через нерівну поверхню цоколю).

3 кінчення 3 зн чимо, що розріз четвертої тер си ністр овге-гор потребує якн йретельнішого вивчення 3 повним комплексом н літичних досліджень. отребують вивчення і розрізи п'ятої т шостої тер с. е допоможе з'ясув ти умови формув ння долини ністр н р нніх ет п х її історії. ут сприятливі умови для вирішення й інших пит нь п леогеогр фії плейстоцену, геоморфології тощо. чевидно, є всі підст ви розгляд ти ділянку долини ністр в околицях овгого як перспективну для створення природоохоронного об’єКт .

1. олянський . . одільські етюди: тер си, леси і морфольогія лицького оділля н д ністром / . . олянський // б. м тем.-природ.-лік р. секції _ . ьвів, 1929. - .20. - 191 с.

2. цишин . сновні ет пи верхньопліоцен-нижньоплейстоценового морфо-, літогенезу долини ністр у р йоні лицького ридністер'я / . цишин // існ. ьвів. ун-ту. ер. геогр. - 2010. ип. 38. - . 379-394.

3. цищин . т пи плейстоценового морфогенезу долини ністр у лицькому ридністер'ї н основі н лізу лесово-грунтових покривів тер с / . цишин, . огуцький // iсн. н-ту рхеології. - 2008. - ип. 3. - . 3-7.

4. Alexandrowicz S.W. Analiza malakologiczna w badaniach osadów czwartorzędowych / S.W. Alexandrowicz // Geologia. - Kraków, 1987. - T. 13. - Z. 1-2. - S. 3-240.

5. Alexandrowicz W.P. Malakofauna lessów Naddniestrza halickego / W.P. Alexandrowicz, A. Boguckyj, R. Dmytruk, M. Lanczont // Studia Geologica Polonica. Lessy i paleolit Naddniestrza halickego (Ukraina). - Krakow, 2002. - Vol. 119. - Cz. III. - S. 253-290.

6. Lessy i paleolit Naddniestrza halickiego (Ukraina) / Studia geologica Polonica / [Pod red. T. Madeyskiej]. - Kraków, 2002. - Vol. 119. - Cz. III. - 391 s.

7. Ložek V. Quartärmollusken der Tschechoslovakei / V. Ložek // Rozpravy Ustredniho Ustavu Geologickeho. - Praha, 1964. - T. 31. - 374 p. 


\section{HIGH TERRACES OF THE DNISTER RIVER AT ENVIRONS OF THE VILLAGE DOVHE}

\section{A. Bogucki*, A. Jacyshyn*, R. Dmytruk*, O. Tomeniuk, D. Zavalij, M. Lanczont**}

*Ivan Franko National University of Lviv, . Doroshenko St., 41, UA - 79000 Lviv, Ukraine

**Maria Curie-Sklodowska University, Kraśnicka St., 2 cd, PL-20718 Lublin, Poland

At environs of the village Dovhe in Ivano-Frankivs'k region (oblast) the fourth, fifth and sixth terraces of the Dnister River are well developed. They occur in the close vicinity to each other and are fully exposed. The authors published sections of the V and VI terraces earlier. In the present paper the description of the IV terrace is given.

All the high terraces of the Dnister River from environs of Dovhe show the geological substrate below the alluvial cover. The section over the substrate parts is composed of the gravelly-to-pebbly channel alluvial deposits, sand and clay deposits of the alluvial plain, and covering subaerial loess and paleosoil deposits of the various thicknesses. In the fourth terrace, the complete section of the first and the second phases of the Korshiv paleosoil are exposed, with the entire thickness equal $3.6 \mathrm{~m}$. Therefore, the ancient Korshiv paleosoil complex in the Dovhe section can be the stratotype section for the Forecarpathians.

Key words: terrace, alluvium, subaerial cover, loess-soil series, buried soils, soil complexes, paleolit.

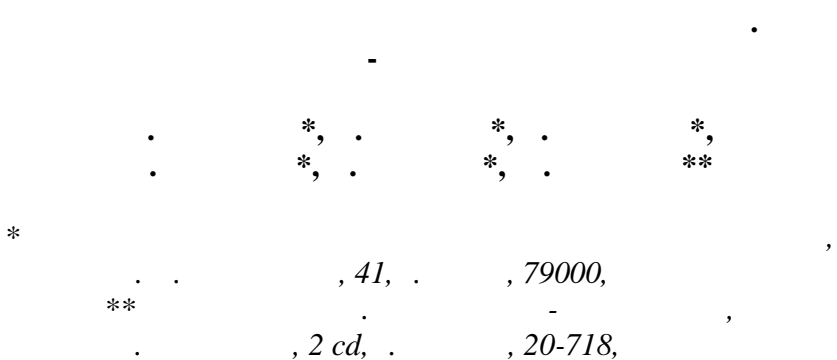

окрестностях с. олгое в но- $\mathrm{p}$ нковской обл. прекр сно р звиты четверт я, пят я, шест я н дпойменные терр сы нестр . жно, что они н ходятся рядом и доступны для изучения н всю высоту. зрезы пятой и шестой терр с опубликов ны н ми р нее. иже приведено подробное опис ние четвертой терр сы.

се высокие терр сы нестр окрестностей олгого цокольные. их строении, кроме цоколя, хорошо выделяются русловой гр вийно-г лечниковый ллювий, пойменный песч носупесч но-суглинистый ллювий и покровные суб эр льные лессово-почвенные толщи $\mathrm{p}$ зличной мощности. $\mathrm{p}$ зрезе четвертой терр сы предст влены очень полные профили первой и второй ф з коршевского почвообр зов ния общей мощностью 3,6 м. оэтому коршевский ископ емый почвенный комплекс в р зрезе олгое может быть опорным для редк рп тья.

лючевые слов : терр с , ллювий, суб эр льные покровы, лессово-почвенные серии, погребенные почвы, почвенные комплексы, п леолит. 